\title{
American Soldier Zombie Tales: The Desperate, the Drafted, and the Dead
}

\author{
Kristine $\operatorname{Hart}^{1} \&$ John Paul ${ }^{2}$ \\ ${ }^{1}$ The Center for Community and Civic Engagement, Washburn University, Topeka, Kansas, USA \\ ${ }^{2}$ Department of Sociology and Anthropology, Washburn University, Topeka, Kansas, USA \\ Correspondence: John Paul, Department of Sociology and Anthropology, Washburn University, Topeka, Kansas \\ 66621, USA. Tel: 1-785-670-1608. E-mail: john.paul1@washburn.edu
}

\author{
Received: February 8, 2015 Accepted: March 22, 2015 Online Published: May 31, 2015 \\ doi:10.5539/ells.v5n2p1 URL: http://dx.doi.org/10.5539/ells.v5n2p1
}

\begin{abstract}
This paper explores an under-examined subgenre of the scholarly zombie canon: soldiers who have returned as the undead. The primary theme of this paper is that zombies are an apt metaphor for military soldiers. Indeed, throughout the history of U.S. warring actions, soldiers often seem to be treated like faceless, disposable units sent to enforce the will of the country. So stated, our work explores the warrior zombie in literature and film, from three distinct time periods: the US Indian Wars, World War I, and the Afghan and Iraqi conflicts. The specific works examined include two short literary works, "Ghost Dance" by Sherman Alexie and "Herbert West: Reanimator" by H.P. Lovecraft, and one film, "Homecoming" written by Sam Hamm and directed by Joe Dante. We contend that the military zombie is a metaphor for persons conscripted into combat against their own social, political, and economic wills.
\end{abstract}

Keywords: zombies, military, Marxist analysis, literary and movie analysis

\section{Introduction}

This paper introduces and critically explores an under-examined subgenre of the scholarly zombie canon: soldiers who have returned as the undead. The primary theme of this paper is that zombies are an apt metaphor for military soldiers. Indeed, throughout the history of US warring actions, soldiers often seem to be treated like faceless, disposable units sent to enforce the will of the country. Further, they are often the anonymous mass that has been conscripted (metaphorically, "turned" into combatants) against their own social, political, and economic wills. While conscription in a historical context generally means compulsorily, obliged, or forced military service - we use the term more broadly to also include self-selected, economically motivated volunteers who come from social groups that lack economic or career opportunities in civilian life.

Regarding compulsory military service, America has fought conflicts with drafted forces on five occasions: the Civil War, World War I, World War II, Korea, and Vietnam. But, as we argue here, all wars have been fought, symbolically, with "conscripted" forces. For example, going back to the time of the US Indian Wars (1775-1842), most US military combatants were persons with limited societal opportunities. As Rickey Jr. (1963) writes:

All of the enlisted men of the Indian Wars army were volunteers. Each of them, for varying reasons, had seen fit to "take on" of his own free will. Few were educated, many were illiterates, and they have little left behind them... In the years from 1865 through the 1980's many recruits were recent immigrants... [and] a large percentage of recruits entered the army from the bottom of the economic ladder, or had fallen from an intermediate rung... as one recruit stated: "he was bankrupt and did not know what else to do, so he enlisted" (Rickey Jr., 1963, pp. 17-18).

Even in the contemporary conflicts in Afghanistan (2001-2014) and Iraq (2003 to 2011), military service has fallen disproportionately on less affluent Americans who are more likely to volunteer. Weinstein (2011, Paragraph 4, lines 1-4) notes, this service is more like conscription with:

The act of stop-loss orders (which allows the Army unilaterally to keep soldiers for up to 18 months beyond the date their enlistment is scheduled to terminate), multiple deployments, and the plucking of reservists and guardsmen for active duty, many 'volunteer' service members have had to make big involuntary sacrifices reminiscent of the lottery days. 
In light of this, a core secondary exploration of this work is also the examination of the ways by which systems of power and social stratification can enslave and transform persons into "zombies." In this analysis, we are aided by the scholarly contributions of Marxist literary theory (Tyson, 2006; Richter, 2007), and this will be detailed in a later section of this paper.In our analysis of the "conscripted" warrior zombie in literature and film, we choose three distinct time periods: the US Indian Wars, World War I, and the Afghan and Iraqi conflicts. The specific works examined include two short literary works, "Ghost Dance" by Sherman Alexie and "Herbert West: Reanimator" by H. P. Lovecraft, and one film, "Homecoming" written by Sam Hamm and directed by Joe Dante.However before an analysis of these works commences, we first make a working definition of the zombie and detail its amorphous power as a vehicle of social commentary and its relationship to war.

\subsection{Defining the Zombie}

According to Kyle Bishop (2010, pp. 12-13), the zombie is not only a "fundamentally American creation," but also unique among all monsters in that it "has no germinal Gothic novel from which it stems [and] no primal narrative that established and codified its qualities or behaviors" in the same way that, for example, Bram Stoker's Dracula did for vampires. This has allowed writers the freedom to interpret and reinvent the monster as they see fit. Thus, following the genre's freedom to define the zombie as one see's fit, we will define it as possessing the following common characteristics: (1) the zombie is the reanimated corpse of a formerly living person; (2) the will of a zombie is subordinate to some monomaniacal drive, whether for living flesh, violence, revenge, or even resistance of the tyranny of entropy itself; (3) the zombie, for the most part, is considered faceless and disposable - and within this framework, the zombie should be considered to be a liminal figure: a person once human but now dehumanized, and who is corporeal yet supernatural.

\subsection{The Connection Between Zombies and War}

There is a long history of fallen soldiers being reanimated in literature. For example, evidence of this "genre" goes as far back as the 1st century C.E. when the poet Lucan wrote his epic civil war poem "Pharsalia." Written in approximately 61-65 C.E., it contains reference to a witch named Erichtho who reanimates the corpse of a dead soldier who in turn foretells the assassination of Caesar (Young, 2011, p. 37). Ultimately, Pharsalia is a poignant story with a clever social and political warning: namely, that the dead will always come back to haunt society and reap consequences on the living (whether it be the emotional pain of loss or the institutional chain reaction, i.e., political or social upheaval, that often follows war and soldiers' deaths).

Indeed, war has a significant impact on the appearance of the zombie in storytelling and numerous scholars (Newitz, 2008; Bishop, 2010; Christine \& Lauro, 2011) highlight this reality. For instance, in a ninety-nine year (1910-2009) content analysis of zombie tales, Newitz (2008) found the frequency "noticeably increased after a huge political or social event caused mass fear, chaos, or suffering. That's why World War II, Vietnam, and the Iraq War are all followed by a zombie rush" (Paragraph 4, lines 2-4).

Why is this the case? Skal (2001) suggests that as unprecedented numbers of dead, wounded, and maimed soldiers come back and are being uneasily reintegrated into American society, the zombie becomes an expression of our collective anxiety and these stories are an attempt to help us deal with those worries. Further, because soldiers are primarily trained to operate as a unit, respond to orders without hesitation or critical analysis, and neutralize or kill the identified "other" without empathy, they mirror many characteristics of the zombie. As Sorcha NíFhlainn (2011, p. 140) writes:

Soldiers are trained to dehumanize themselves when in combat, and their subjects are terrorized by the actions of the dehumanized combatant... [As a result of the horrors of war] they are, in varying degrees, zombified through the process of dehumanization, mental breakdowns, and self-annihilation, hybridized, transfigured, and mutilated to the point where all rational thinking and reason is abandoned or removed, leaving a destructive and destroyed shell in its wake.

In other words, soldiers are expected to internalize zombie-like characteristics in preparation for their war related duties. Additionally, as a result of the violence, dehumanization, and horrors of war itself, the soldier is more prone to becoming a psychological zombie. Taken altogether then, the rise of fallen soldiers into the ranks of an army of the undead is a natural connection, especially within the context of war. Not only are zombie-soldier stories a social and cultural critique of the body politic (specifically a government's role in sending soldiers to die in war), they also mirror the collective anxiety of seeing and dealing with the physically scarred (the visually "monsterous") and the psychologically transformed (zombified) soldier. 


\subsection{The Marxian Legacy in the Analysis of the Zombie Soldier}

Marxism is a general term for the legacy of thought associated with the philosopher Karl Marx (1818-1883) who concerned himself primary with social stratification and the ways by which systems of power enslave and emancipate persons. To put it simply, the core focus of Marxism is the relationship between:

[t]he "haves" and the "have-nots," between the bourgeoisie - those who control the world's natural, economic, and human resources - and the proletariat, the majority of the global population who live in substandard conditions and who have always performed the manual labor...that fills the coffers of the rich (Tyson, 2006, p. 54).

In this context, the proletariat are faceless commodities that are used as units of production until they are no longer able to serve their purpose - at which point they are considered to be disposable. Given this definition, it is not a difficult leap to connect these characteristics of the proletariat to soldiers, particularly those from the enlisted and noncommissioned officer ranks who have been sent to the frontline. Soldiers in the United States traditionally come from the proletariat rather than the monied, powerful classes who control and dictate their actions for both benevolent and malevolent reasons. When soldiers are conscripted or drafted into their military service or come from communities where military service is seen as a way out that can move them up the socioeconomic ladder, it further highlights their sense of powerlessness over their own fates and actions even more. It is this moral devaluation of people who make up the proletariat and a narrow definition of their human capital that makes it easier for the elites to send them to early deaths on the battlefield. This in turn sets the stage for the horrors associated with their reanimation. After all, if soldiers are considered to be the "throw-away" people in our society and taught that it is their civic and moral duty to kill, then why would we expect them to be different the second time they walked among the living. At the same time, they become more frightening to the power elite because they no longer recognize their commands and therefore challenge their power and ability to control society in a way that benefits them (i.e., the proletariat uprising).

With this as a guide, we reiterate that a core theme of this paper is that zombies are an apt metaphor for US military soldiers. Throughout the history of US warring actions, soldiers often seem to be treated like faceless, mass, and disposable units sent to enforce the will of our country. We now turn to an analysis of the "conscripted" warrior zombie in literature and film.

\section{Sherman Alexie's Indian Wars and His "Ghost Dance"}

In 1868, the United States government signed the Fort Laramie Treaty with the Greater Sioux Nation, giving them all the land within the current borders of South Dakota, all of Nebraska north of the North Platte River and parts of North Dakota, Montana and Wyoming. In this treaty the U.S. "pledged to use its military to prevent its citizens from trespassing" and that no future treaty for cession for any portion of the newly created "reservation" would be valid or enforced (Churchill, 1992, p. 163).

This treaty lasted until 1874 when rumors of gold in the Black Hills caused the government to send Lieutenant Colonel George Armstrong Custer and the Seventh Cavalry to confirm the find. When the Greater Sioux Nation refused to sell the land, Sioux Affairs were transferred to the War Department and a mandate was issues that they must relocate to military posts or would be considered hostile and punished for noncompliance. Most choose not to comply, which was subsequently seen as an act of war and in 1876, the US, sent several thousand troops, including the Seventh Cavalry, to address the situation (Churchill, 1992, p. 163). In what became known as the Battle of the Little Bighorn (or "Custer's Last Stand"), General Custer and a combined force of Sioux and Northern Cheyenne defeated over 200 enlisted soldiers in the Seventh Cavalry.

While Custer perished in this battle meant to force compliance from the Greater Sioux Nation, it was not long until the US government claimed the land they desired and confined the indigenous occupants to small reservations. It was under this framework that the soldiers of the Seventh Cavalry and Lieutenant Colonel George Armstrong Custer are introduced in Alexie's (2002) fictional zombie story.

\subsection{Synopsis and Analysis}

Alexie's "Ghost Dance"is a short story that revolves around FBI agent, Edgar Smith who is sent to investigate an alleged incident of grave robbing at the Little Big Horn historical site. Upon arriving at the site, the scene was much worse than he could imagine with 256 open graves, "all of them filled with blood, pieces of skin, and unidentifiable body parts" (Alexie, 2002, p. 348). In addition to this, the agents found the bodies of two white state police officers and two Indians. What was left of one of the officers "was smeared all over his cruiser...the other cop was spread over a twenty-foot circle, his blood and bones mixed with the blood and bones of one Indian. 
Edgar, through unexplained dreams and visions, comes to "see" the "reality" of what the reader already knows happened here. Two white, racist officers (the older of the two most proud of his longstanding violent persecution of Indians) picked up two Native American hitchhikers, brutally beat them with nightsticks, took them to the site of Custer's Last Stand and proceeded to execute them for the sole crime of being Indian on the anniversary of the famous battle. As their blood soaked into the earth, it awoke the long dead corpses of Custer's Seventh Calvary. "Hundreds of zombies rose from their graves, devoured the cops, and proceeded to wreak havoc on the surrounding population, regardless of racial or cultural identity" (Elliott, 2007, p. 20).In the end, Edgar is unable to stop the visions and the zombies, leaving a largely uncontrolled mass that still poses a threat to society. Thus, we are reminded that every war has its "after-war"-a series of lasting consequences born from war: anger, rage, seemingly senseless violence, and the creation of the physically and mentally wounded who often exist in a realm fundamentally disconnected from life (see: Finkel, 2013).

However, in many ways, this story can also be read as a critique of violence spawned by economic desperation and alienation. As previously mentioned, Alexie's soldiers-turned-zombies were mostly illiterate and uneducated men. Many were recent immigrants and most all found themselves at the bottom of the economic ladder with limited resources or options. This said, many of these soldiers were desperate to do whatever needed to be done in order to survive, including embracing the racist and colonial mindset of their new country to prove their loyalty and essentialness. While it was the government and military leaders who set the tone for their behavior, they were the ones on the ground expected to carry out the "extermination" in lockstep with no sympathy or hesitation. Thus, in a symbolic reading of Alexie's tale, the zombie soldiers are a reconstruction of an exploited military class. They are a group whose continued rage is explained, in part, by their meager existence in life and their early death in a racist and exploitative war. While the soldiers may have longed for something more than disenfranchisement in life, the only power they can manage in death is purposeless violence. This then is one of the core points of this work: it is does not take a monster to commit a monstrosity-rather it is inequality and war itself that acts as a social mutation that turns men into inarticulate monsters.

Further, given the unresolved ending to "Ghost Dance," Alexie reminds us that moral conclusions or clean resolutions to works of inequality, horror and war are often absent. Alexie's work raises the question of responsibility for atrocities committed in wartime - does the blame rest predominantly on the soldiers and the historical and cultural structure of racism to which they were part-or does blame lie to the economic and political structures of inequality which compelled the soldiers enlistment and monstrous transformation?

\section{The World into which H.P. Lovecraft's World War I Zombies Were Born}

The First World War was a social and moral morass that birthed macabre scientific innovation and taboo technology. For example, it is known that the British and Germans used one ton of chemical weapons per fatality by such means during World War I (Easterbrook 2003). Further, in this historical context, it is also widely known that world governments supported doctors in medical schools and scientists at universities to develop new, horrific ways to kill large numbers of people-and to cultivate gear that would give troops the sense that they would be protected from innovations like chemical weapons (Kristof 1995, Emmerson 2013). As scholars and documentarians write:

The World War of 1914-18 was the first man-made catastrophe of the 20th century...The Great War was without precedent...never had so many nations taken up arms at a single time. Never had the battlefield been so vast. Never had the fighting been so gruesome...World War I marked the first use of chemical weapons, the first mass bombardment of civilians from the sky, and the century's first genocide...the end result [was] a war where nine million people had died on the battlefield and a world that was forever changed (PBS.org 2006, Prologue).

It was this new form of war and the horrific use of technological and scientific innovations that set the stage for H.P. Lovecraft's "Herbert West: Reanimator" (1922). As the forefather of the modern Gothic zombie, H.P. Lovecraft wrote several short stories that dealt with corpses coming back to life and introduced some of the most frightening attributes that we now think of as being characteristically zombie-like. One of his stories that fits this genre is "Herbert West: Reanimator" (1922). In this tale, two doctors perform experiments on the corpses of soldiers with the intention of finding a way to bring them back to life.

\subsection{Synopsis and Analysis}

While there is no clear-cut evidence that WWI was the impetus of "Herbert West: Reanimator," it is our opinion that Lovecraft's temporal and cultural proximity to the "Great War" had to be influential. As a sign of a fearful response to the destruction brought about by World War I, Lovecraft's zombie was a creature that offered a new vision of what it meant to be (post)human in a time of war: the reduction of men to disabled bodies, traumatized 
and deadened beings, and grotesque military creatures augmented to be weapons of war. As a case in point, "Herbert West" comes across as a blatant critique of the deaths of millions of people. The narrator in the story states:

Many men have related hideous things, not mentioned in print, which happened on the battlefields of the Great War. Some of these things have made me faint, others have convulsed me with devastating nausea, while still others have made me tremble and look behind me in the dark...[there was] an abundant supply of freshly killed men in every stage of dismemberment. (Lovecraft, 1922, pp. 415-416).

Indeed, it is possible to interpret his tale as a sympathetic text highlighting the plight of the soldier by offering a critique of the political and material contexts of societies that generated human forces of destruction. In this way, it may also be read as attentive call to the human capital needed to conduct the war itself. For example, Ford (2001) identifies that over twenty-four million American men were registered for the draft for the First World War-and that nearly half a million of those persons were immigrants (again mirroring the experience of immigrants who fought in the US Indian Wars). Additionally, regarding the extreme measures of conscription, Hochschild (2012) reports that on the European front, anti-war resisters were often forcibly inducted into the army-while the draft was also viewed as a way to bring about, "the complete removal of useless and idle youths" (Hochschild, 2012, p. 329). Altogether, approximately 70 million worldwide combatants fought in Word War I (Zimmer, 1999).

Returning to Lovecraft's horror-tale, we note that the chief protagonist, Doctor Herbert West (an enlisted military officer serving the Allied forces) experiences his own dehumanization and zombie-like transformation brought on by war. Initially celebrated as a surgical specialist tasked with saving lives, he nevertheless becomes a monster obsessed with death. Consider the following passage:

Dr. West had been avid for a chance to serve as surgeon in a great war... What he wanted was not a thing which many persons want...It was, in fact, nothing more or less than an abundant supply of freshly killed men in every stage of dismemberment...[he] needed fresh bodies because his life-work was the reanimation of the dead (Lovecraft, 1922, pp. 415-416).

Ultimately Herbert West's experiments became more important to him than working to save the injured. In fact, West got to the point where he was glancing with a "kind of hideous and calculating appraisal" at vibrant young men with vigorous physiques imaging their potential in death (Lovecraft, 1922, p. 419). Here the narrator of "Reanimator" relates that: "Still more shocking were the products of some experiments — grisly masses of flesh that had been dead, but that West waked to a blind, brainless, nauseous animation" (Lovecraft, 1922, p. 419). As the doctors' skills increased in this area, the behaviors exhibited by the zombies became more complex and more dangerous for all involved. In particular, upon their "reanimation," the human subjects exhibited violent behavior and a compulsion to attack, kill and bite/eat the living. Lovecraft described them as having outlines that were "human, semi-human, fractionally human, and not human at all" (1922, p. 421). In particular, one was depicted as "a repellent hulk whose bluish face seemed half eaten away by some unknown malady," while another was characterized as a cannibalistic monster (1922, p. 420).

All told, Lovecraft's story highlights several themes harmonious to our thesis. First, when read with a critical mindset, it illustrates a view that those who have power over the lives of others often view them as expendable. Here, Lovecraft's ugly truth is that soldiers routinely die for others, and his "zombies" become a Marxian expression of the commodification of the warrior body - a tool of social and political capital resurrected (drafted) over and over again to fight in seemingly endless conflicts. Finally, it is also metaphorically suggested here that the horrors of war zombiefy, dehumanize, and mutilate all, including the surgeon Dr. West as well as the soldiers under his knife.

\section{Sam Hamm and Joe Dante's Zombies from the Afghan and Iraq Wars}

On September 11, 2001, the United States was attacked on its own shores in a way not known since the attack on Pearl Harbor and which greatly exceeded the 1941 attack in terms of civilian casualties. The United States government responded by identifying various Islamic groups and Arab political regimes as the enemy. This led to troops being deployed to Afghanistan in 2001 and Iraq in 2003 to fight in wars of retaliation in order to increase the perceived security of the United States.

These wars have been fought with an all volunteer military. However, as with the other wars included in this paper, there is still an element of obliged conscription, particularly toward those enlisted soldiers who have low socioeconomic influence in society. As a case in point, in 2008, the American Civil Liberties Union (ACLU) released a report with the following revelations related to tactics in the recruitment of youth under the age of 18: 
Wartime enlistment quotas have placed increased pressure on military recruiters to fill the ranks of the armed services necessary to carry out sustained U.S. military operations in Iraq and Afghanistan... The U.S. military's practice of targeting low-income youth...for recruitment, in combination with exaggerated promises of financial rewards for enlistment, undermines the voluntariness of their enlistment (ACLU, 2008, p. 3).

Additionally, O’Hare and Bishop (2006) note that:

In time of war...rural Americans are paying the ultimate sacrifice in disproportionately high numbers...soldiers from rural America are dying at a higher rate than soldiers from big cities and suburbs...The high death rate for soldiers from rural areas is linked to the higher rates of enlistment of young adults from rural America...[which is] possibly linked to diminished opportunities there. Transitioning from youth to adulthood is more problematic in rural U.S. because there are fewer job opportunities. Young adults in rural areas are less able to secure a foothold in the economy (2).

Hamm and Dante's "Homecoming" (2006) is a work based in this reality. Their movie is set a few weeks prior to an American presidential election during a time when an unnamed war in response to a terrorist attack was being fought overseas. The Republican incumbent, whose voice sounds like former President George W. Bush, has launched a reelection campaign based on patriotism and the success of the war effort. Given these cues, it is not hard to guess that the military actions being referred to are the Afghan and Iraq Wars.

\subsection{Synopsis and Analysis}

The tale begins with Republican political operative, David Murch, appearing on the "Marty Clark" political talk show opposite a mother who pleads to know what her son died for in this war. David, becoming somewhat melancholy, responds that his dead older brother fought in Vietnam and then states that if he could make one wish it would be for the woman's son to come back from the dead so that he could tell the American people how important it is that this war is being fought. In a case of "be careful what you wish for," dead soldiers from the current conflict rise from their coffins to engage in one last mass act meant to get their country to hear what they have to say about fighting and dying in this war--they go to their polling places to vote. After voting, they are able to rest in peace knowing that their voices have been heard, and promptly "die" again.

As the zombie soldiers are not hurting anyone, the Republican strategists are initially elated and support their right to vote as they assume the zombie soldiers are voting Republican to show their support for a cause they believed in and died for. That changes when one of the zombie soldiers that retained his ability to speak is seen on television saying the following:

Have you been to war sir? Have you ever seen men get killed? I've seen men get killed sir for a lie. Women and children killed for a lie. I've seen my friends killed for a lie. I was killed for a lie. We want one thing - we want to vote and we'll vote for anyone who ends this evil war.

After this public statement, the government declared all zombie soldiers to be a public health threat pending further tests and rounded them up and put them in quarantine. Another Republican operative, Jane Cleaver, went on television a short time later to make the following statements:

The fact is, Marty, they've studied these creatures and they have no higher brain function...On top of which, Marty, these things - they're turncoats; they've betrayed their country and their government and their fellow soldiers and they're giving aid and comfort to the enemy. Now as I've said, they're brain dead maybe they're not responsible maybe they won't go to hell...Monsters, traitors there's one solution for both-mobs, torches, pitchforks.

In a laboratory where the government is trying to determine what is happening, the following conversation happens between David and his superior, Kurt Rand:

Kurt: You can't kill 'em - God knows we've tried...shoot 'emthey keep on coming, cut 'em up in pieces and the pieces keep coming... David: He feels it Kurt-you see...he feels pain. Kurt: Oh hell, he volunteered...Kurt: Something to think about huh—a soldier that can't be killed. Takes a lickin' and keeps on tickin.' I mean, shoot, our recruitment numbers are in the sewer. If we could keep the same dead GIs out on the battlefield forever, that's like the answer to a prayer.

In the end, the zombie soldiers only kill those that used their deaths for their own gain - the politicians and the pundits. Additionally, it was only when the zombie soldiers find out that their votes were withdrawn from the final election count (thereby keeping the incumbent and his war policies in the White House) that they decided they needed to get their point across in a stronger way. Still non violent to the general public or living soldiers, 
they "called up" their fallen comrades from previous wars and conducted a march on Washington where they replaced the current political structure with their own. In a segment late in the film, David provides the following observation in voice over as a zombie soldier walks in the rain:

The face of this war had always been ugly. We'd always tried to hide it from the public.

But then they were among us these dead young men - these monsters-demanding only that we look at that face. To acknowledge what we had done.

As with the previous two works, it is the immoral actions of the living that bring the dead back. In "Homecoming," it is the self-serving, media propagated wish of a political operative within a political-military machine that causes those who died in Afghanistan and Iraq to rise from their coffins and graves. Here however, the soldier returned, not to reassure the public of the continued need to fight, but to protest the act of war and the "art" of war making for political gain. As noted in the earlier discussion of the socioeconomic composition of soldiers sent to fight in Afghanistan and Iraq, these zombie soldiers likely found themselves to be disenfranchised in life, both before and after they enlisted. Unfortunately, despite the invitation to have their voices heard by those very entities that had disempowered them in life, they found themselves equally or more disenfranchised in death.

There are two scenes that help to illustrate this point. In one, a discussion of how to neutralize this newly identified enemy takes place where David mentions that maybe they should handle them like they do every other war veteran when they return home- - ignore them." In the other scene, when asked why he did not talk even though he had the ability to do so, a zombie soldier replied that it hurt to speak. These references speak to the treatment that soldiers often receive upon returning home and magnify the idea that they are expendable. Critically speaking, this mirrors the history of veterans protest movements, wherein many felt as though their anti-war voices were silenced, unless of course, they could be spun to support the policies of the political-military machine (Decker \& Paul, 2013).

\section{Conclusion}

This paper explores an under-examined subgenre of the scholarly zombie canon: soldiers who have returned as the undead. The primary theme of this paper was that zombies have unfortunately become an apt metaphor for military soldiers. Indeed, throughout the history of U.S. warring actions, soldiers have often been treated like faceless, disposable units sent to enforce the will of the country. With this in mind, we symbolically examined persons depicted in literature who were conscripted (metaphorically, "turned" into combatants) against their own social, political, and economic wills.

Collectively, we find that the zombie soldier, across all three works, was reanimated as a result of monstrous actions among the living (i.e., racism, random violence, and the exploitment of the dead for material and/or political gain). Further, in all cases, the zombies were a result of elite manipulation and the sacrifice of the poor. Informed and guided by a critical Marxian perspective, we find that it's been the poor who have done most of the dying in the majority of the U.S. military conflicts (Ricky Jr., 1963; Keith, 2005; O'Hare \& Bishop, 2006; ACLU, 2008; Weinstein, 2011). So stated, this paper was also written with a degree of empathy toward these literary "monsters." Here then, we argue that it does not take a monster to commit a monstrosity-rather the forces of inequality and war act as social mutations that turn persons into such monsters. Ironically, it is the zombie soldier's inclusion in this genre that gives voice to those made silent by war. By reanimating the dead, one has the opportunity to confront the various economic and political structures that often dehumanize and disempower the living soldier.

\section{References}

Alexie, S. (2002). Ghost Dance. In M. Chabon (Ed.), McSweeney's Mammoth Treasuryof Thrilling Tales (pp. 341-353). New York, NY: Vintage Press.

American Civil Liberties Union. (2008). Soldiers of Misfortune: Abusive U.S. Military Recruitment and Failure to Protect Child Soldiers. https://www.aclu.org/sites/default/files/pdfs/humanrights/crc_report_20080513.pdf

Bishop, K. (2010). American Zombie Gothic: The Rise and Fall (and Rise) of the Walking Dead in Popular Culture. Jefferson, NC: McFarland \& Company, Inc.

Christine, D., \& Lauro, S. J. (Eds.). (2011). Better of Dead: The Evolution of the Zombie as Post-Human. New York: Fordham University Press. http://dx.doi.org/10.5422/fordham/9780823234462.001.0001

Churchill, W. (1992). The Earth is Our Mother: Struggles for American Indian Land and Liberation in the 
Contemporary United States. In M. A. Jaimes (Ed.), The State of Native America: Genocide, Colonization, and Resistance (pp. 139-187). Cambridge, MA: South End Press.

Decker, S. K., \& Paul, J. (2013). The Real Terrorist was Me: an Analysis of Narratives Told by Iraq Veterans Against the War in an Effort to Rehumanize Iraqi Civilians and Soldiers. Societies Without Borders, 8, 317-343. Retrieved from https://societieswithoutborders.files.wordpress.com/2014/02/deckerpaulfinal.pdf

Easterbrook, G. (2003). The Nation: Home Security; The Smart Way to Be Scared. The New York Times, Feburary 16. Retrieved from http://www.nytimes.com/2003/02/16/weekinreview/the-nation-home-security-the-smart-way-to-be-scared.h tml? pagewanted $=$ all\&src $=$ pm

Elliott, M. A. (2007). Custerology: The Enduring Legacy of the Indian Wars and George Armstrong Custer. Chicago, IL: The University of Chicago Press. http://dx.doi.org/10.7208/chicago/9780226201481.001.0001

Emmerson, C. (2013). 1913: In Search of the World Before The Great War. New York: PublicAffairs.

Erlanger, S. (2013). A Weapon Seen as Too Horrible, Even in War. The New York Times, September 6. Retrieved from http://www.nytimes.com/2013/09/07/world/middleeast/a-weapon-seen-as-too-horrible-even-in-war.html

Finkel, D. (2013). Thank You for Your Service. New York: Sarah Crichton Books.

Ford, N. G. (2001). Americans All!: Foreign-born Soldiers in World War One. College Station, TX: Texas A \& M University Press.

Gaffen, F. (1996). Cross-Border Warriors: Canadians in American Forces, Americans in Canadian Forces. Dundurn.

Hochschild, A. (2012). To End All Wars: A Story of Loyalty and Rebellion, 1914-1918. Mariner Books.

"Homecoming." (2006). Masters of Horror. Writ. Sam Hamm. Dir. Joe Dante. Starz, DVD.

Keith, J. (2005). Rich Man's War, Poor Man's Fight. The University of North Carolina Press.

Kristof, N. (1995). Unmasking Horror-A special report.; Japan Confronting Gruesome War Atrocity. New York Times, $\quad$ March $17 . \quad$ Retrieved from http://www.nytimes.com/1995/03/17/world/unmasking-horror-a-special-report-japan-confronting-gruesome -war-atrocity.html?pagewanted $=$ all\&src $=$ pm

Lovecraft, H. P. (1922 [2010]). "Herbert West: Reanimator." H.P.Lovecraft's Complete Works (pp. 403-421). Amazon Digital Services, Inc.

Newitz, A. (2008). War and Social Upheaval Cause Spikes in Zombie Movie Production. io9: We Comefrom the Future. Retrieved

from http://io9.com/5070243/war-and-social-upheaval-cause-spikes-in-zombie-movie-production

NíFhlainn, S. (2011). All Dark Inside: Dehumanization and Zombification in Postmodern Cinema. In D. Christine \& S. J. Lauro (Eds.), Better of Dead: The Evolution of the Zombie as Post-Human. New York: Fordham University Press.

O'Hare, W., \& Bishop, B. (2006). U.S. Rural Soldiers Account for a Disproportionately High Share of Casualties in Iraq and Afghanistan. Carsey Institute at the Scholars' Repository. Retrieved fromhttp://scholars.unh.edu/cgi/viewcontent.cgi?article $=1015 \&$ context $=$ carsey

PBS.org. (2006). The Great War and the Shaping of the 20th Century: Prologue. PBS.org. Community Television of Southern California, 1996-2004. Retrieved from http://www.pbs.org/greatwar/

Richter, D. H. (Ed.). (2007). The Critical Tradition: Classical Texts and Contemporary Trends. Boston, MA: St. Martin's Press.

Rickey, Jr. D. (1963). Forty Miles a Day on Beans and Hay: The Enlisted Soldier Fighting the Indian Wars. Norman, OK: University of Oklahoma Press.

Skal, D. J. (2001). The Monster Show: A Cultural History of Horror. London: Faber \& Faber.

Tyson, L. (2006). Critical Theory Today: A User-Friendly Guide (2nd ed.). New York: Routledge.

Weinstein, A. (2011). Last Vietnam Draftee Finally Leaving Army.MotherJones. Retrieved fromhttp://www.motherjones.com/mojo/2011/07/last-vietnam-draftee-finally-leaving-army-video

Winter, J., \& Baggett, B. (1996). The Great War and the Shaping of the 20th Century. Penguin Studio. 
Young, J. B. (2011). Deathly Erichtho as Vital to Lucan's Bellum Ciuile. Marshall Digital Scholar: Theses, Dissertations and Capstones. Retrieved from http://mds.marshall.edu/cgi/viewcontent.cgi?article=1294\&context=etd

Zimmer, W. (1999). Art; at Yale, the Great War Recalled. The New York Times. Retrieved fromhttp://www.nytimes.com/1999/08/29/nyregion/art-at-yale-the-great-war-recalled.html

\section{Copyrights}

Copyright for this article is retained by the author(s), with first publication rights granted to the journal.

This is an open-access article distributed under the terms and conditions of the Creative Commons Attribution license (http://creativecommons.org/licenses/by/3.0/). 